\title{
Dengue fever with Methicillin-Resistant Staphylococcus Aureus coinfection: A fatal combination
}

Dear Sir,

As you may be aware, the incidence of Dengue fever (DF) has massively increased over the past few years. It is even regarded as the most rapidly spreading mosquito-borne viral disease in the world. According to the WHO, DF is an acute febrile illness of 2 to 7 days duration, with two or more associated symptoms like headache, arthralgia/myalgia, retro-orbital pain, rash, hemorrhagic manifestations (petechiae, positive tourniquet test) and leucopenia. There are three phases in DF. The initial febrile phase is characterized by fever, headache, myalgia and leucopenia; and lasts for 2 to 7 days. This is followed by the critical phase lasting for 24 to 48 hours. The patients experience a decline in temperature with thrombocytopenia, increase in haematocrit levels and increase in capillary permeability. Haemorrhage, myocarditis, hepatitis and encephalitis may also be seen. Surviving this period, the patients enter the recovery phase, where there is a gradual resorption of the fluid from the extracellular compartment. The platelet counts show a rising trend and haematocrit levels start stabilizing. ${ }^{1}$

A 65 year old male from rural area presented to the Emergency department with complaints of high grade fever of 7 days duration with no other associated symptoms. He was not a known case of any comorbid condition and was not on any regular medications. On examination, he was febrile with a temperature of $102^{\circ} \mathrm{F}$. His other vitals and systemic examinations were normal. His investigation reports showed thrombocytopenia (platelet 85,000/cumm), leucopenia (2,900/cumm) and elevated liver enzymes (SGOT $225 \mathrm{U} / \mathrm{L}$ and SGPT $275 \mathrm{U} / \mathrm{L}$ ). Other parameters like renal functions, electrolytes, HbA1c, prothrombin time and activated thromboplastin time were normal. Dengue serology was reactive for NS1 antigen and IgM. Viral markers (HIV, HBsAg, anti HCV, HAV IgM), malarial smear, Weil Felix test, Leptospirosis serology and Widal test were negative. ECG, chest X-Ray and urine microscopy were normal.
He was managed symptomatically with intravenous fluids, pantoprazole and paracetamol. His platelet counts showed a further decline to 52,000/cumm over the next 3 days and continued to be febrile. By day 4 of admission (day 11 of illness), his platelet counts started rising $(98,000 / \mathrm{cumm})$. His temperature spikes started reducing to $100^{\circ} \mathrm{F}$. Blood cultures sent during the fever spikes grew MethicillinResistant Staphylococcus Aureus (MRSA). He was started on injection vancomycin (as per culture and sensitivity reports). His platelet counts started normalizing. On day 7 of admission, patient went into septic shock and bradycardia, and expired.

Staphylococcous aureus is the most virulent among the staphylococcal group. It can cause infection by toxin and non-toxin mediated mechanisms. The incidence is higher among those with diabetes, injection drug users, HIV infection, skin abnormalities, prosthetic valves and those on hemodialysis. ${ }^{2}$

As mentioned earlier, the febrile phase of DF has duration of 2 to 7 days. When fever exceeds this period, a co-infection should be suspected. Malaria, leptospirosis, hepatitis A, typhoid, Staphylococcus schleiferi, Chikungunya and Zika virus co-infections have been reported with DF. ${ }^{3-8}$ MRSA co-infection has been reported with influenza. ${ }^{9}$ A co-infection of DF with MRSA is a rare scenario, showing the fatal nature of the combination.

Robin George Manappallil ${ }^{1}$, Avinash Sarpamale ${ }^{2}$ ${ }^{1}$ Consultant-Physician, ${ }^{2}$ Resident, Department of Internal Medicine, Baby Memorial Hospital, Calicut, Kerala, India 
Address for correspondence:

Dr. Robin George Manappallil,

Consultant-Physician, Department of Internal Medicine, Baby Memorial Hospital, Calicut, Kerala, India 673004.

E-mail: drrobingeorgempl@gmail.com Mobile: 0091-8547753396

\section{REFERENCES}

1. WHO. Dengue: guidelines for diagnosis, treatment, prevention and control. New edition. Geneva: World Health Organization;2009.

2. Lowy FD. Staphylococcal Infections. In: Kasper, Fauci, Hauser, Longo, Jameson, Loscalzo (ed). Harrison's Principles of InternalMedicine. 19 ${ }^{\text {th }}$ ed. McGraw Hill education. pp. 954 - 960.

3. Epelboin L, Hanf M, Dussart P, Ouar Epelboin S, Djossou F, Nacher $\mathrm{M}$, et al. Is Dengue and Malaria co-infection more severe than single infection. Malaria J 2012; 11:(142).
4. Chopdekar KA, Patil SS, Lilani SP, Joshi AA and Chowdhary A. Concomitant leptospirosis and dengue infections. JIACM 2014;15(3-4):258-259.

5. Volchkova E, Umbetova K, Belaia O, Sviridova M, Dmitrieva L, Arutyunova $D$, et al. Co-infection of dengue fever and hepatitis Ain a Russian traveller. ID Cases 2016; (5): 67-68.

6. Bansal R, Bansal $P$ and Tomar LR. Typhoid and dengue coinfection: case reports. Trop Doct 2015;45(1):52-53.

7. Manappallil RG. Staphylococcus schleiferi coinfection in dengue fever. Asian Journal of Medical Sciences 2017; 8(4): 62-63.

8. Villamil-Gómez WE, Rodríguez-Morales AJ, Uribe-García AM, González-Arismendy E, Castellanos JE, Calvo EP, et al. Zika, dengue and chikungunya co-infection in a pregnant woman from Colombia. International Journal of Infectious Diseases 2016;(51):135-138.

9. Chertow DS, Kindrachuk J, Sheng ZM, Pujanauski LM, Cooper K, Nogee D, et al. Influenza A and methicillin-resistant Staphylococcus aureus co-infection in rhesus macaques - A model of severe pneumonia. Antiviral Res 2016;129:120-129.

\section{Authors Contribution:}

RGM- Concept and design of case report, reviewed the literature, manuscript preparation, critical revision of manuscript and treating physician; AS- Medicine resident- In-charge

Dr. Robin George Manappallil: (1) http://orcid.org/0000-0003-3973-6800

Source of Support: Nil, Conflict of Interest: None declared. 